\title{
Segregation analysis of dominant osteogenesis imperfecta in Italy
}

\author{
M Mottes, L Cugola, N Cappello, P F Pignatti
}

\begin{abstract}
We have performed linkage analysis in seven Italian families, in which mild osteogenesis imperfecta (OI) segregated as a dominant trait, by means of six DNA restriction fragment length polymorphisms (RFLPs) of type I collagen genes. OI type I was linked to the $\alpha 1(I)$ gene (COL1A1) in two families, and to the $\alpha 2(I)$ gene (COL1A2) in one family. OI type IV segregated with COL1A2 in two families. In two OI type I families, the molecular genetic data were insufficient for exclusion of one gene. Four DNA polymorphisms were particularly informative for cosegregation analysis of $\mathrm{OI}$ in Italian kindreds.
\end{abstract}

New data at the biochemical, genetic, and molecular levels have indicated in recent years the association of osteogenesis imperfecta (OI) with various mutations in the genes (COL1A1 and COL1A2) which encode for type I procollagen. ${ }^{2}$ The striking clinical heterogeneity $^{3}$ of brittle bone disease is emphasised by the molecular data which have been accumulating in the last three years; each mutation studied so far is a different one. They occur sporadically in the severest cases, while they are transmitted in an autosomal dominant fashion in milder cases. Mutations which

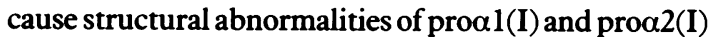
chains are more commonly found in severe variants of OI and can often be shown by the biochemical analysis of collagen $\mathrm{I}^{4}$

In milder OI variants (OI type I and type IV according to Sillence $e t \mathrm{al}^{3}$ ), which can be dominantly inherited, analysis and identification of the mutations are far less accessible since they often do not produce

Istituto di Scienze Biologiche, Facoltà di Medicina e Chirurgia, Università di Verona, Strada le Grazie, I-37134 Verona, Italy.

M Mottes, L Cugola, P F Pignatti

Dipartimento di Genetica, Biologia e Chimica Medica, Università di Torino, Italy.

N Cappello

Correspondence to Professor Pignatti.

Received for publication 28 December 1989.

Accepted for publication 8 January 1990. evident alterations in the collagen chains. Such mutations may, for instance, decrease the relative rate of synthesis of proal chains and result in lower than normal levels of structurally unaltered collagen type I molecules in OI type I. ${ }^{56}$ Segregation analysis with RFLPs in affected families can be of great use in these cases, in order to localise the mutation in either gene. ${ }^{78}$ Thus, prenatal diagnosis of $\mathrm{OI}$ may become feasible. ${ }^{9} 10$

In a recent study, we determined COLlAl and COL1A2 RFLP haplotype frequencies in a large sample of random, normal, Italian subjects. ${ }^{11}$ As a result of this analysis we indicated which RFLPs might be more informative for the identification of the affected gene in familial type I collagen diseases in this population.

Here, we report our genetic studies on some Italian families with dominantly inherited forms of OI. Our data agree with the above indications, and show the usefulness of COL1A1 and COL1A2 RFLP haplotype determinations in segregation analysis in affected families in the Italian population. They also confirm the different associations reported between disease and affected locus in type I and type IV forms of osteogenesis imperfecta.

\section{Patients}

Seven pedigrees in which OI segregated as a dominant trait were considered: a total of 53 subjects was examined, 28 of whom were diagnosed as affected by OI. All subjects who participated in the genotypic characterisation were seen by at least one of the authors and a detailed clinical history was recorded for each of them. Classification was according to Sillence $e t a l .^{3}$ In all families, parental relationships were checked for variable numbers of tandem repeat (VNTR) DNA polymorphisms with probes YNH24 and EFD64.2 $2^{12}$ in $M s p I$ and $R s a I$ DNA digests respectively, as described previously. ${ }^{13}$

\section{Methods}

DNA was prepared from peripheral blood, digested with the appropriate restriction endonuclease, electrophoresed on agarose gels, transferred to Hybond C filters, and hybridised with probes which 
had been labelled with ${ }^{32} \mathrm{P}$ by multiprimer directed synthesis. Hybridisation conditions were as previously described. ${ }^{11}$

Segregation of COL1A1 and COL1A2 was analysed in the pedigrees by means of three restriction site polymorphisms for each locus, as previously described. " The following RFLPs were used: FG2/MspI, 2FC6/RsaI, and NST70/RsaI for COL1A1, and $\mathrm{NJ} 3 / E \operatorname{coRI}, \mathrm{Hf} 32 / R s a \mathrm{I}$, and $\mathrm{Hf} 32 / M s p I$ for COL1A2. Table 1 shows the eight possible RFLP haplotype combinations at the COL1A1 and COL1A2 loci; these haplotype numbers are used in the pedigree representations. Lod score analysis was performed with the M-LINK program. ${ }^{14}$ In some cases, fibroblasts were grown by standard methods from skin biopsies obtained from affected subjects and

Table I RFLP haplotypes at collagen type I loci.

\begin{tabular}{|c|c|c|c|c|c|c|}
\hline & \multicolumn{3}{|c|}{ COLlAI } & \multicolumn{3}{|c|}{ COL1A2 } \\
\hline & $\begin{array}{c}\text { MspI } \\
\text { FG2 }\end{array}$ & $\begin{array}{l}R s a I \\
2 \text { FC6 }\end{array}$ & $\begin{array}{c}\text { RsaI } \\
\text { NST70 }\end{array}$ & $\begin{array}{c}E c o R I \\
\text { NJ3 }\end{array}$ & $\begin{array}{l}\text { RsaI } \\
\text { Hf32 }\end{array}$ & $\begin{array}{l}M s p \text { I } \\
\text { Hf32 }\end{array}$ \\
\hline 1 & + & + & + & + & + & + \\
\hline 2 & + & + & - & + & + & - \\
\hline 3 & + & - & + & + & - & + \\
\hline 4 & + & - & - & + & - & - \\
\hline 5 & - & + & + & - & + & + \\
\hline 6 & - & + & - & - & + & - \\
\hline 7 & - & - & + & - & - & + \\
\hline 8 & - & - & - & - & - & - \\
\hline
\end{tabular}

Table 2 OI linkage to collagen type I loci.

\begin{tabular}{lcc}
\hline Pedigree No & COL1Al & COL1A2 \\
\hline 1 & $0 \cdot 6$ & - \\
2 & - & $0 \cdot 0$ \\
3 & - & $1 \cdot 2$ \\
4 & $0 \cdot 6$ & $0 \cdot 0$ \\
5 & $-\cdot 2$ & -0 \\
6 & $0 \cdot 3$ & $0 \cdot 0$ \\
7
\end{tabular}

Lod scores were calculated for the two genes at \%ero recombination frequency. Discordance is indicated by a dash. healthy relatives. Electrophoresis of collagens was performed by sodium dodecylsulphate-polyacrylamide gel electrophoresis. ${ }^{4}$ Total RNA was purified from approximately $10^{8}$ fibroblasts by the guanidinium isothiocyanate method. ${ }^{15}$ Northern blot analysis was performed by standard methods using proal $(\mathrm{I})$ and proa2(I) full length cDNA probes, kindly provided by Dr F Ramirez.

\section{Results}

Families were chosen from among a wider number of Italian OI patients, as they clearly showed a dominant pattern of inheritance of the disease and were large enough to allow segregation analysis to be performed. Linkage to either collagen type I gene was investigated by segregation analysis of COLlAl and COL1A2 RFLPs. The results obtained are shown in detail in the figure; under each pedigree symbol, COL1A1 and COL1A2 RFLP haplotypes are shown. In five families $(1,2,3,5$, and 6$)$, the affected locus was identified by showing discordance at one locus. In two families (4 and 7), association of the disease with either collagen type I gene locus was not possible as neither could be excluded. An additional COL1A2 StuI RFLP ${ }^{16}$ was used in the analysis of the two pedigrees which were not informative for the other six polymorphisms: no additional information was gained.

From these data, lod scores at zero recombination frequency were calculated for the seven families, and are reported in table 2 . The low values are the result of the small number of meioses available for each family.

Table 3 summarises the affected locus and the diagnostic features common to each family, notwithstanding a remarkable variability in clinical severity among the affected members.

Electrophoretic analysis of collagens obtained from skin fibroblasts of at least one or more affected members from families $1,2,3$, and 7 showed no structural alteration. Preliminary data on collagen type I mRNA levels in family 1 indicate a decrease in proal(I) mRNAs compared to normal controls (subject III.6).

Table 3 Clinical and genetic features of $O I$ pedigrees.

\begin{tabular}{|c|c|c|c|c|c|c|c|c|}
\hline No & Sclerae & $\begin{array}{c}\text { No of } \\
\text { fractures: }\end{array}$ & $\begin{array}{c}\text { Presenile } \\
\text { hearing loss }\end{array}$ & $\begin{array}{l}\text { Dentinogenesis } \\
\text { imperfecta }\end{array}$ & Deformity & $\begin{array}{l}\text { Joint } \\
\text { laxity }\end{array}$ & Type ${ }^{3}$ & $\begin{array}{l}\text { Concordant } \\
\text { locus }\end{array}$ \\
\hline $\begin{array}{l}1 \\
2 \\
3 \\
4 \\
5 \\
6 \\
7\end{array}$ & $\begin{array}{l}\text { Blue } \\
\text { White } \\
\text { Blue } \\
\text { Blue } \\
\text { White } \\
\text { Blue } \\
\text { Blue }\end{array}$ & $\begin{array}{l}>10 \\
>10 \\
\quad 5-10 \\
<5 \\
>10 \\
<5 \\
>10\end{array}$ & $\begin{array}{l}\text { Yes } \\
\text { No } \\
\text { Yes } \\
\text { Yes } \\
\text { No } \\
\text { No } \\
\text { No }\end{array}$ & $\begin{array}{l}\text { No } \\
\text { No } \\
\text { No } \\
\text { No } \\
\text { Yes } \\
\text { No } \\
\text { No }\end{array}$ & $\begin{array}{l}\text { Moderate } \\
\text { Moderate } \\
\text { No } \\
\text { No } \\
\text { Moderate } \\
\text { Moderate } \\
\text { Moderate }\end{array}$ & $\begin{array}{l}\text { No } \\
\text { No } \\
\text { Yes } \\
\text { No } \\
\text { No } \\
\text { No } \\
\text { Yes }\end{array}$ & $\begin{array}{l}\text { IA } \\
\text { IVA } \\
\text { IA } \\
\text { IA } \\
\text { IVB } \\
\text { IA } \\
\text { IA }\end{array}$ & $\begin{array}{l}\text { COLlA1 (h } 2) \\
\text { COLlA2 (h } 5) \\
\text { COLlA2 (h } 5) \\
\text { COL1A1 \& COL1A2 } \\
\text { COL1A2 (h 1) } \\
\text { COLlA1 (h 6) } \\
\text { COL1A1 \& COL1A2 }\end{array}$ \\
\hline
\end{tabular}

* = number of fractures reported at the time of observation.

$\mathrm{h}=$ haplotype (see table $\mathbf{l}$ and the figure). 

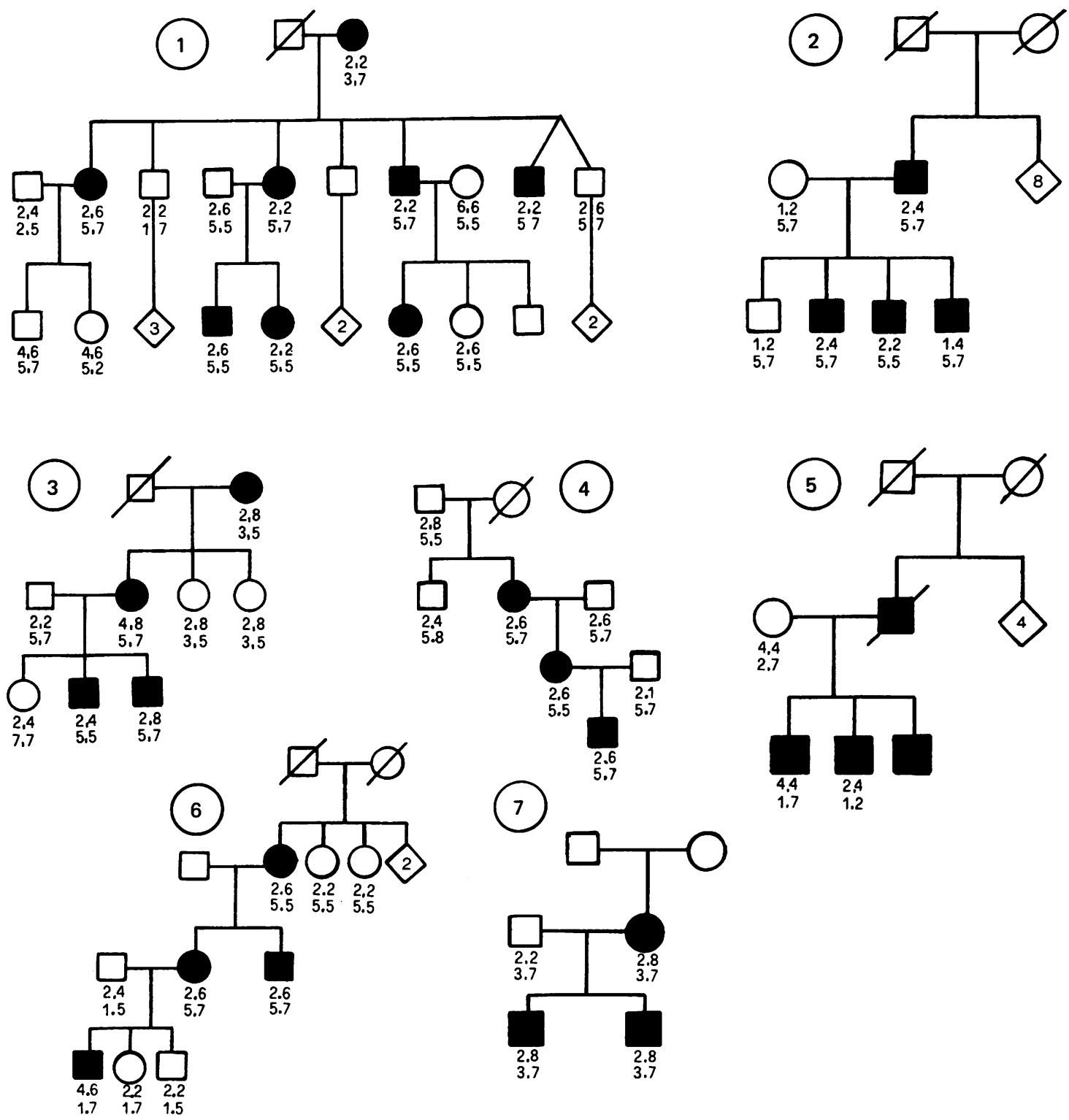

OI pedigrees. Numbers under symbols indicate COLIAI (upper row) and COLIA2 (lower row) haplotypes (see table 1). RFLPs were determined on DNA samples from each family member indicated.

Discussion

The data reported in this paper show that, using RFLP cosegregation analysis, the affected locus could be identified in five out of seven families affected by dominantly inherited forms of osteogenesis imperfecta.

In our recent study of COL1A1 and COL1A2 haplotype frequencies in the Italian population, ${ }^{11}$ we emphasised the potential usefulness of four restriction site dimorphisms (FG2/MspI and 2FC6/RsaI for COL1A1 and NJ3/EcoRI and Hf32/RsaI for COL1A2) for linkage analysis, owing to their high PIC values in our population. Indeed, their combined use was sufficient to gain the necessary information in this study, while the other RFLPs used (NST70/RsaI for COL1A1, Hf32/MspI and 4.1 kb StuI for COL1A2) turned out to be of little interest for diagnostic 
purposes, owing to their low PIC values. Our data show that it was possible to determine the affected gene even when no collagen alteration was readily detectable. Prenatal or preclinical diagnosis can be made available to the families in which the affected gene has been identified.

It is interesting to note that the number of subjects typed is not a sufficient previous indicator of the possibility of identifying the affected locus by segregation analysis. Three subjects were enough in family 5 , while four were not sufficient in family 7 , neither were the seven typed members distributed over four generations in family 4 . For familial cases of OI where segregation analysis is not informative, new probes, as well as biochemical or other molecular evidence, might help to identify the affected locus. It is also worth noting that new dominant mutations seem to have occurred recently in five $(2,4,5,6$, and 7$)$ out of seven families with mild OI.

New mutations in mild dominantly inherited OI were described in 12 out of 71 families examined by Sillence $e t a l^{3}$ and in the majority of severe (type II and type III) OI cases. ${ }^{17} 18$ An effect of paternal age on the frequency of $\mathrm{OI}$ mutations has been described. ${ }^{19}$ Mean paternal age at birth of the first OI case in the five families described here was 30 years (range 27 to 35 years), which was similar to normal control values.

In OI type IV pedigrees (families 2 and 5), the disease segregated with COL1A2. In OI type I cases, the disease segregated with COL1A1 in two pedigrees (families 1 and 6), and with COL1A2 in one family (3). Our observations are in agreement with the reported data, which ascribe OI type IV to mutations occurring at COL1A2, ${ }^{20}{ }^{21}$ while OI type I has been shown to be linked to both loci. ${ }^{8}$ While a severe autosomal recessive form of $\mathrm{OI}$ unlinked to collagen type I genes has been reported, ${ }^{22}{ }^{23}$ all dominant OI pedigrees studied so far have shown linkage with collagen type I loci. At present, the hypothesis of another locus involved in dominant $\mathrm{OI}$ can therefore be discarded.

We are indebted to the participating family members, and to the many colleagues who contributed by bringing OI families to our attention and collecting blood samples and skin biopsies, among them Drs F Antoniazzi, R Aldegheri, F Bertoldo, and C Esposito. We thank the Centre for the Study of OI of Valeggio s/Mincio (Verona) for collaboration, and Drs $\mathbf{R}$ Tenni, M Valli, and G Cetta for the biochemical analysis of collagens. We also thank Ms $R$ Galavotti for excellent technical assistance and Drs F Ramirez, B Sykes, and Y Nakamura, for kindly providing their DNA probes. LC was the recipient of a fellowship from the Italian OI Association. The work was supported by grants from the Italian Ministry of University and Scientific and Technologic Research
(MURST), and by the National Research Council "Progetto Finalizzato Biotecnologie" and "Progetto Finalizzato Ingegueria Genetica".

1 Byers PH. Inherited disorders of collagen gene structure and expression. Am f Hum Genet 1989;34:72-80.

2 Prockop DJ, Costantinou CD, Dombrowski KE, et al. Type procollagen: the gene-protein system that harbors most of the mutations causing osteogenesis imperfecta and probably more common heritable disorders of connective tissue. Am $\mathrm{F} \mathrm{Hum}$ Genet 1989;34:60-7.

3 Sillence DO, Senn AS, Danks DM. Genetic heterogeneity in osteogenesis imperfecta. $\mathcal{J}$ Med Genet 1979;16:101-16.

4 Tenni R, Cetta G, Dyne K, et al. Type I procollagen in the severe non-lethal form of osteogenesis imperfecta. Hum Genet 1988;79: 245-50.

5 Rowe DW, Shapiro JR, Poirier M, Schlesinger S. Diminished type I collagen synthesis and reduced alpha $1(I)$ collagen messenger RNA in cultured fibroblasts from patients with dominantly inherited (type I) osteogenesis imperfecta. F Clin Invest 1985;76:604-11.

6 Barsh GS, David KE, Byers PH. Type I osteogenesis imperfecta: a non functional allele for proalpha 1 (I) chains of type I procollagen. Proc Natl Acad Sci USA 1982;79:3838-42.

7 Tsipouras P, Borresen AL, Dickson LA, Berg K, Prockop DJ, Ramirez F. Molecular heterogeneity in the mild autosomal dominant forms of osteogenesis imperfecta. Am 7 Hum Genet 1984;36:1172-9.

8 Sykes B, Ogilvie D, Wordsworth P, Anderson J, Jones N. Osteogenesis imperfecta is linked to both type I collagen structural genes. Lancet 1986;ii:69-72.

9 Sykes B, Ogilvie D. Prenatal diagnosis in osteogenesis imperfecta. Ann NY Acad Sci 1988;543:136-41.

10 Tsipouras P, Schwartz RC, Goldberg JD, Berkowitz RL, Ramirez F. Prenatal prediction of osteogenesis imperfecta (OI type IV): exclusion of inheritance using a collagen gene probe. f Med Genet 1987;24:406-9.

11 Mottes M, Cugola L, Pignatti PF. Haplotype frequencies of the collagen type I genes in the Italian population. Hum Genet 1989;83:369-72.

12 Nakamura Y, Leppert M, O'Connell P, et al. Variable number of tandem repeat (VNTR) markers for human gene mapping. Science 1987;235:1616-22.

13 Gasparini P, Trabetti E, Savoia A, Marigo M, Pignatti PF. Frequency distribution of tandem repeats DNA polymorphisms in the Italian population. Hum Hered 1990;40:61-8.

14 Lathrop GM, Lalouel JM. Easy calculations of lod scores and genetic risks on small computers. Am F Hum Genet 1984;36: 460-5.

15 Maniatis T, Fritsch EF, Sambrook J. Molecular cloning: a laboratory manual. New York: Cold Spring Harbor Laboratory, 1982:196.

16 Falk CT, Schwartz RC, Ramirez F, Tsipouras P. Use of molecular haplotypes specific for the human proalpha $2(\mathrm{I})$ collagen gene in linkage analysis of the mild autosomal dominant forms of osteogenesis imperfecta. Am $\mathcal{F}$ Med Genet 1986;38:269-79.

17 Young ID, Thompson EM, Hall CM, Pembrey ME. Osteogenesis imperfecta type IIA: evidence for dominant inheritance. f Med Genet 1987;24:386-9.

18 Thompson EM, Young ID, Hall CM, Pembrey ME. Recurrence risk and prognosis in severe sporadic osteogenesis imperfecta. f Med Genet 1987;24:390-405.

19 Carothers AD, McAllion SJ, Paterson CR. Risk of dominant mutation in older fathers: evidence from osteogenesis imperfecta. F Med Genet 1986;23:227-30.

20 Wenstrup RJ, Tsipouras P, Byers PH. Osteogenesis imperfecta type IV. Biochemical confirmation of genetic linkage to the proalpha 2(I) gene of type I collagen. F Clin Invest 1986;78: 1449-55.

21 Superti-Furga A, Pistone F, Romano C, Steinmann B. Clinical variability of osteogenesis imperfecta linked to COL1A2 and associated with a structural defect in the type I collagen molecule. F Med Genet 1989;26:358-62.

22 Aitchison $\mathrm{K}$, Ogilvie D, Honeyman M, Thompson E, Sykes B. Homozygous osteogenesis imperfecta unlinked to collagen I genes. Hum Genet 1988;78:233-6.

23 Daw S, Nicholls AC, Williams M, Sykes B, Pope FM. Autosomal recessive osteogenesis imperfecta. Excess post translational modification of collagen not linked to either COLlAl or COL1A2. F Med Genet 1988;25:275A. 